\section{and}

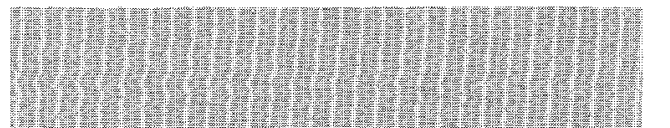

oAK RIDGE
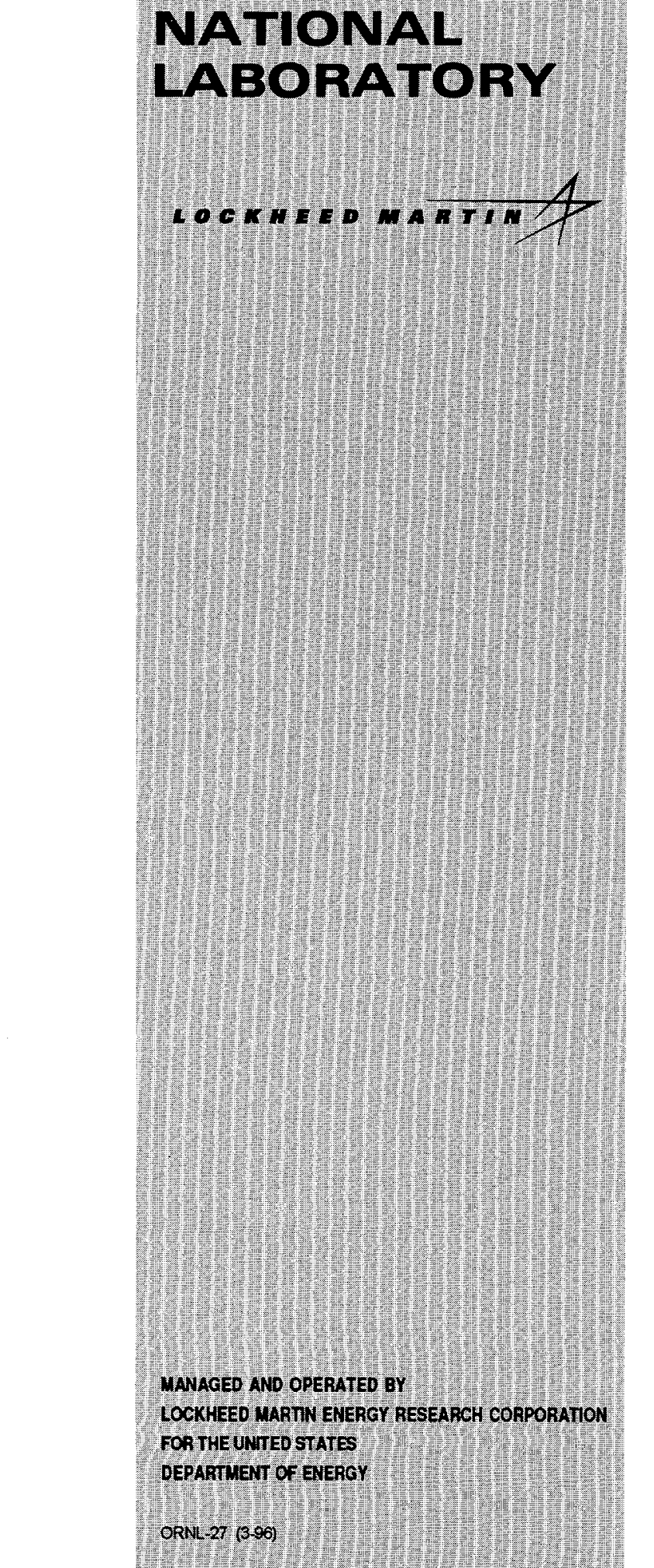

\section{CRADA Final Report for}

CRADA Number ORNL 94-0289
RECEIVED SEP 251997 osti

\title{
Optimal Access to Large Databases Via Networks
}

\author{
J. K. Munro \\ Oak Ridge National Laboratory
}
Robert L. Fellows and Daniel Phifer Oak Ridge K-25 Site

Michael R. Carrick and Nina Tarlton

Stephens Engineering Company

Prepared by the

Oak Ridge National Laboratory

Oak Ridge,Tennessee 37831

managed by

Lockheed Martin Energy Research

Corporation

for the

U.S. Department of Energy

under contract DE-AC05-96OR22464

DSTRIOUTION OF THS DOCUMENT is UNA

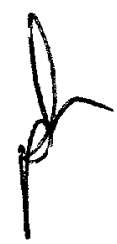




$$
\text { ORNL/M- }-6080
$$

C/ORNL94-0289

CRADA Final Report

for

CRADA Number ORNL-94-0289

\title{
OPTIMAL ACCESS TO LARGE DATABASES VIA NETWORKS
}

\author{
J. K. Munro \\ - Oak Ridge National Laboratory \\ Robert L. Fellows and Daniel Phifer \\ Oak Ridge K-25 Site \\ Michael R. Carrick and Nina Tarlton \\ Stephens Engineering Company \\ Prepared by the \\ OAK RIDGE NATIONAL LABORATORY \\ managed by \\ LOCKHEED MARTIN ENERGY RESEARCH CORP. \\ for the U.S. Department of Energy \\ under contract DE-AC05-96OR22464
}

This work was supported through a CRADA with Stephens Engineering Company, Lanham, Maryland, sponsored by the Laboratory Technology Research Program, Office of Energy Research, U.S. Department of Energy, under contract DE-AC05-96OR22464 with Oak Ridge National Laboratory, managed by Lockheed Martin Energy Research Corporation. 


\section{DISCLAMIER}

Portions of this document may be illegible in electronic image products. Images are produced from the best available original document. 


\title{
Optimal Access to Large Databases via Networks
}

\author{
John K. Munro, Jr., Principal Investigator \\ Instrumentation and Controls Division \\ Oak Ridge National Laboratory \\ Robert L. Fellows and Daniel Phifer \\ Analytical Services Department \\ Oak Ridge K-25 Site \\ Michael R. Carrick and Nina Tarlton \\ Stephens Engineering Company \\ Lanham, MD
}

This work was supported through a CRADA with Stephens Engineering Company, sponsored by the Laboratory Technology Research Program, Office of Energy Research, U. S. Department of Energy, under contract DE-AC05-96OR22464 with Oak Ridge National Laboratory, managed by Lockheed Martin Energy Research Corporation.

\begin{abstract}
A CRADA with Stephens Engineering was undertaken in order to transfer knowledge and experience about access to information in large text databases, with results of queries and searches provided using the multimedia capabilities of the World Wide Web. Data access is optimized by the use of intelligent agents. Technology Logic Diagram documents published for the DOE facilities in Oak Ridge $(K-25, X-10, Y-12)$ were chosen for this effort because of the large number of technologies identified, described, evaluated, and ranked for possible use in the environmental remediation of these facilities. Fast, convenient access to this information is difficult because of the volume and complexity of the data. WAIS software used to provide full-text, field-based search capability can also be used, through the development of an appropriate hierarchy of menus, to provide tabular summaries of technologies satisfying a wide range of criteria. The menu hierarchy can also be used to regenerate dynamically many of the tables that appeared in the original hardcopy publications, all from a single text database of the technology descriptions. Use of the Web environment permits linking many of the Technology Logic Diagram references to on-line versions of these publications, particularly the DOE Orders and related directives providing the legal requirements that were the basis for undertaking the Technology Logic Diagram studies in the first place.
\end{abstract}




\section{Statement of the Objectives}

The primary objective of this CRADA was to provide World Wide Web access to a large text database, the Oak Ridge National Laboratory (ORNL) Technology Logic Diagram (TLD), in full text searchable form, through a collaborative effort with Stephens Engineering Company of Lanham, Maryland.

An important secondary objective of this CRADA was to train a couple of the Stephens' technical staff in the use of the World Wide Web for electronic publishing of scientific and technical information and to use the ORNL TLD as an example of a collection of related documents with a range of types of content. Other objectives included developing interactive interfaces to assist with constructing queries to extract information efficiently from the text databases and designing data structures for reliable construction and maintenance of the text databases themselves.

\section{Benefits to the Funding DOE Office's Mission}

Benefits to the Office of Energy Research included full-text searchable access to the ORNL TLD, especially to the set of more than 600 technologies identified for use in assisting with the environmental remediation and waste management of the ORNL facilities and waste storage areas. These technologies are currently available in fulltext searchable form, but only a crude user interface now exists with a minimal explanation of how to use it.

The technologies described in the TLD could also greatly benefit other federal agencies, particularly the military service branches having to close bases where major environmental remediation and waste management problems exist. In the early stage of this work, the investigators learned of new efforts being initiated to identify technologies needed for remediation and waste management at several army bases. Much of this work would be a duplication of effort to produce more documents covering the same material that was to be put on the Web as part of this CRADA. Considering the effort that went into producing the ORNL TLD, elimination of the duplication in effort in the specific cases cited would have saved tax payers many millions of dollars.

One of the objectives of Stephens Engineering Company was to develop experience and capabilities that would open the way to follow-on work for DOE and other federal agencies in providing Web access to other large text databases of wide interest to scientists, engineers, and policy makers.

\section{Technical Discussion of Work Performed by All Parties}

The ORNL TLD was originally published as three large volumes in a limited edition. All text material was stored on 3.5 inch diskettes in WordPerfect 5.1 format. These files had to be converted to ASCII text for use in the text database and to HyperText Markup Language (HTML) for installation on a Web server. Indexing of the text database was done using Wide Area Information Service (WAIS) text management tools. Selected photographs from the printed version of the TLD had to be scanned. What was done and the division of labor is summarized in Table 1. Tasks were organized to minimize time needed to do the work and to allow as much of the work to be done to proceed simultaneously. The activities provided new territory in the use of electronic media and 
computer networks for all participants. Examples of some of the finished Web pages are provided in Appendix A.

Table 1. Approximate Division of Labor

\begin{tabular}{|c|c|c|}
\hline 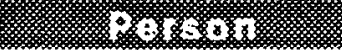 & 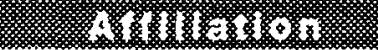 & 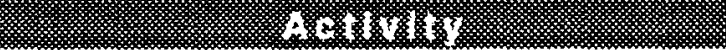 \\
\hline Michael R. Carrick & Stephens Engineering & Re-formatted files for use on the Web. \\
\hline Robert L. Fellows & K-25 Site & $\begin{array}{l}\text { Edited text and selected photographs from } \\
\text { the original published version for use in } \\
\text { the Web version. }\end{array}$ \\
\hline Jonas T. Holdeman & ORNL & $\begin{array}{l}\text { Developed text parser needed to create the } \\
\text { WAIS index for field-based search of the } \\
\text { database of technology descriptions. }\end{array}$ \\
\hline John K. Munro, Jr. & ORNL & $\begin{array}{l}\text { Verified and corrected re-formatted files; } \\
\text { coordinated technical activities; put files } \\
\text { on the Web server. }\end{array}$ \\
\hline Daniel Phifer & K-25 Site & $\begin{array}{l}\text { Scanned photographs and created Adobe } \\
\text { Acrobat formatted version of wiring } \\
\text { diagram. }\end{array}$ \\
\hline
\end{tabular}

The primary technical objective was to optimize access to the TLD information, particularly the technology descriptions. More than 600 technologies were identified, described, and ranked in the TLD effort for ORNL. Because of the thoroughness of this effort, due to experience gained from the preceding effort on the K-25 TLD, and the much wider range of problems to be addressed, preparation of the ORNL technology description database was given the highest priority. It was available in full-text searchable form early in the project with Stephens. This early availability permitted work to begin on development of a hierarchical menu system to provide quick access to tabular summaries of technologies that would be good candidates for remediating particular problems. Several prototype graphical interfaces were constructed to identify factors important to finding an optimal approach to data access.

Those people working on this CRADA who were involved in gathering and publishing the information in the ORNL TLD were surprised by the amount of reorganization of document content that was necessary to take advantage of hypertext link and multimedia capabilities of the Web. Many tables were used in the printed version to summarize technologies most appropriate for solving particular problems that had been identified as needing attention early in the remediation process (e.g., in order to obtain better estimates of clean-up costs). Based on preliminary tests using compound queries with WAIS searches, it appears that many, perhaps most, of these tables can be generated dynamically, as needed. Even more complex search criteria can also be applied to generate highly focused summaries of candidate technologies. Thus much of the printed volume (i.e., tables spanning many pages) can be replaced by queries constructed using a few menu selections that can be used to better express the needs of the reader.

\section{Inventions}

No inventions resulted from this collaboration and none were anticipated. 


\section{Commercialization Possibilities}

Primary commercialization possibilities would be in the form of providing a service to companies and cooperating government agencies (federal, state, and local) engaged in environment remediation and waste management activities at federal facilities.

\section{Plans for Future Collaboration}

There currently are no plans for future collaboration since Stephens Engineering Company went out of business in the spring of 1996. Discussions with another architecture/engineering firm (MTA) to do follow-on work to the Stephens collaboration eventually ended due to a restructuring of the company and departure of the primary scientist interested in leading that effort. A significant decrease in DOE funding in the past couple of years for this type of work also greatly limited what could be done to continue this effort.

\section{Conclusions}

This collaboration got off to a very strong, promising start, which was interrupted by an automobile accident that seriously injured the principal investigator. By the time he was recovered to resume work, base closings and reductions in funding in the defense budgets had severely impacted Stephens Engineering, requiring major staff changes. Efforts were made to recover from these two large impacts. At the point when the project was getting back on track, the economic impact of a series of government shutdowns resulted in Stephens Engineering having to go out of business. Resources remaining at that stage were not sufficient to complete even the minimum goal.

Sufficient progress was made initially to provide a basis for a technical presentation on the project at WATTec 1995 in Knoxville, TN.

Even though several years have elapsed since this collaboration was conceived, the information on remediation technologies is still very useful. Completing the Web implementation of the ORNL TLD today could still save the tax-payer millions of dollars by eliminating duplication of effort. Once available on the Web with a good user interface, maintaining the information on the large set of technology descriptions and keeping that current should save many millions of dollars. There is still no resource like it on the Web. 


\section{APPENDIX A}

Examples of ORNL Technology Logic Diagram Documentation on the Web 


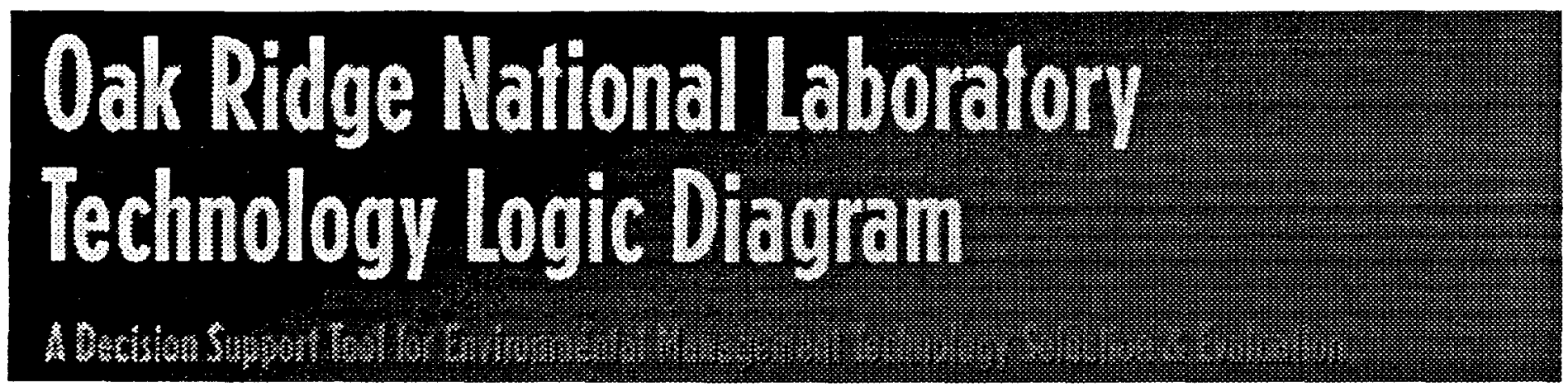

$\because 3-21,4 ! 95$

\section{INTRODUCTION TO THE TECHNOLOGY LOGIC DIAGRAM (TLD)}

\section{BACKCROUND FOR THE ORNL TLD}

\section{ENVIRONMENTAL MANAGEMENT AREAS}

\section{Decontamination and Decommissioning of Buildings and Facilities}

Decontamination and decommissioning operations involve making the transition for, decommissioning, and linally disposing of equipment, buildings, structures, and facilities.

\section{Remedial Action of Contaminated Soils, Groundwater, and Surface Water}

Remedial action operations include activities that monitor, control, remediate, and prevent potential contaminant sources from being released to the environment.

\section{Waste Management}

Waste management operations are aclivities that minimize, treat, store, recycle, or dispose of all radioactive, hazardous, mixed. and sanitary wastes generated as a result of operations at active and inactive facilities.

\section{INFORMATION ABOUT TECHNOLOGIES}

Lists of lechnologies can be gencralled using keywords. phrases (natural language query), Boolean queries, or relevance leedback capabilities of a commercial W $A I S$ server to provide aceess to the Technology Logic Diagram Data Sheets. This server also supports full-text searches for text material associated with individual fields. Ideas for more effective use of the ficld search capability can be identilied by looking at a lew examples of data sheets from the list below.
- CHAR-106-OI
- CHAR-5.OH
- DON.5Tol.
- ROBA-A-OL
- Wimo-2i.n.

A tutorial describing the use of the W $A$ IS query capabilities will be available soon. It will use a smal subsel of the TLD Data Sheets in order to provide faster response times. This subset will also be useful in some cases for trying out new search strategies. The ordering of hield labels is diflerent for the WAIS query interface from the sequence found in the data sheet examples. 


\section{Problems Requiring Action}

Contaminants

Site Areas

Buildings

Substrates

Related Regulatory and Compliance Requirements

Explanations and Guides for Effective Use of TLD Information

Suggested Search Strategies with Examples

Keyword Lists

Some Stected Search Combinations of Interest

Points of Contact for Further Help

User Interaction Services (Fill-in Forms)

User Registration for this Information System

Feedback and Suggestions

Data Sheet Submission

Glossary of Technical Terms Used

B(x)lean Querics definition here

Relevance Feedback delinition here

\section{Acronyms}

This work was supported hrough a CRAD $\Lambda$ with Stephens Enginecring Company, sponsored by the Laboratory Technology Research Program, Oflice of IEnergy Rescarch. U.S. Department of Energy, under contract

DE- $\Lambda$ C05-96OR22464 will ()ak Ridge National Laboratory, managed by Lockhed Martin Energy Research Corporation.

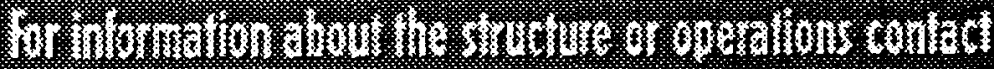

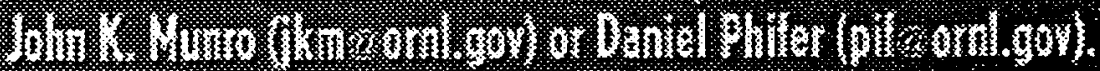

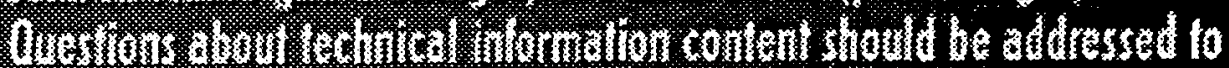

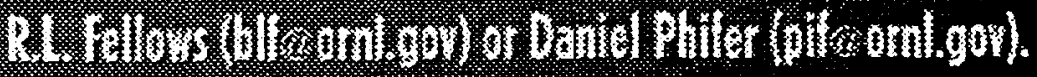




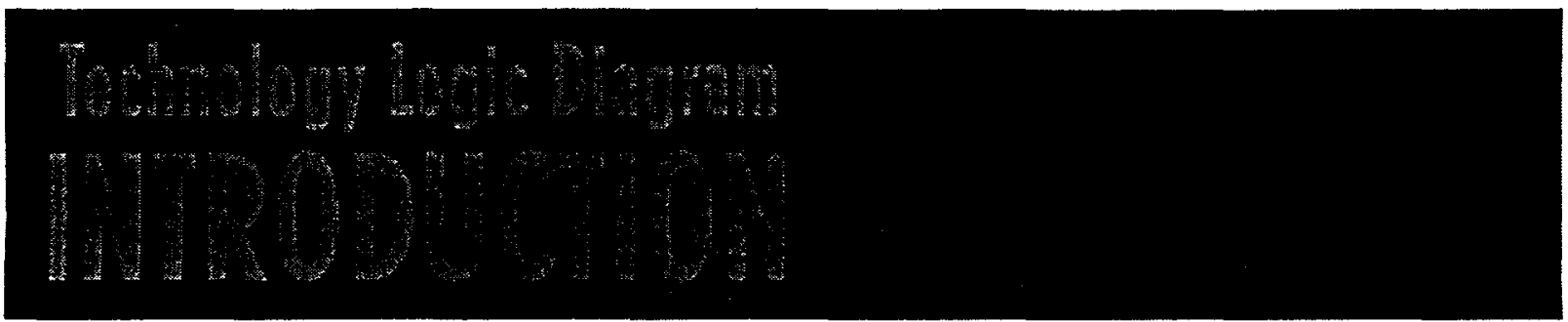

$v 1-2 / 20 / 1995$

\section{TABLE OF CONTENTS}

\section{= 2.1 PURPOSE AND SCOPE}

\subsection{STAFFING FOR THE TLD}

\subsection{TECHNICAL APPROACH}

\subsection{TECHNOLOGY RANKINGS}

\subsubsection{Overall Assessment}

2.4.2 Status of Technologv

2.4.3 Estimates for Time to Maturity

\subsection{REFERENCES}

\subsection{PURPOSE AND SCOPE}

The purpose of the TLD is to provide a planning document for DOE. DOE operating contractors. and private industry that relates the environmental restoration/waste management (ER/WW) problems at ORNL to the technologies that can be used to remediate these problems. In doing so. the status of each potential remediation technology is evaluated. This is a significant focus of the diagram preparation.

Several important aspects impacting implementation of each technology are folded into the evaluation so that the appropriateness of each technology can be evaluated:

1. Potential efficacy of the technology--how successful will its application be to the site problem?

2. Level of maturity of the technology--when can it be applied to site problems?

3. Level of WM required for the technology--what wastes are generated as a result of the use of the technology?

The TLD addresses the enforceable compliance and cleanup agreements that have designated timetables 
for ameliorating the specific site problems. For potentially attractive but immature technologies, or those for which improvement paths (which make them faster, better, safer, and cheaper) are visualized, priorities are assigned to technology development activities.

Because of enforceable compliance agreements, DOE is bound by Executive Order 12088, which requires the Secretary of the Department of Energy to submit a plan and request sufficient funding each year to comply with federal pollution control standards. This document will aid in the annual planning and budget submittals.

This document will address all current D\&D problems that have been identified at ORNL. The technology listings in the diagrams were judged to be reasonably applicable to D\&D at ORNL.

The TLD provides several benefits to the DOE community. The diagram identifies technologies that can be used for EM programs. It serves as a vehicle to identify the deficiencies in technologies that otherwise have potential to (1) foster faster remediation: (2) allow safer project activities; (3) result in better remediation efforts: and (4) allow these projects to be accomplished at a lower cost to DOE and the United States. Improving existing technologies. demonstrating the applicability of promising technologies. developing immature technologies. and supporting fundamental technology investigations are options that DOE can pursue to deploy technologies necessary for successful EM of DOE facilities. The diagram will highlight areas for private industry and university involvement in E.M.

Return to Tible of Contonts.

\subsection{STAFFING FOR THE TLD}

The formulation of the ORNL TLD was led by many of the same professional staff that formulated and published the Oak Ridge K-25 Site Technology Logic Diagram, with participation from across ORR. Although a number of ORNL personnel were involved. about half of the team was selected from other Energy Systems organizations in Oak Ridge, such as the K-25 Site, the Y-12 Plant. Central Engineering. and other DOE contractors. The personnel from these organizations represent input to the TLD from programs under the DOE Deputy Assistant Secretaries of Waste Management (EM-30), Environmental Restoration (EM-40), and Technology Development (EM-50). as well as professionals not associated with these programs. Figure 2.1 shows a staffing plan for the ORNL TLD Team.

Specialists worked as members of each team formed for the subelement categories shown. Representatives from each team served on a coordinating committee. Which functioned as a common communication fortun for the TLD. More than 100 specialists were involved in this effort. The teams (1) compiled the site problems in terms that were applicable to each team: (2) identified and evaluated technologies that could be applied to remediate the problems: (3) furnished. through the technology evaluation. information on the opportunities that were evident for development and improvement in each technology: and (4) furnished the requirements for deployment of these developed and improved technologies.

Technology evaluation was a significant component of the TLD effort. Team members identified potential technologies, but it was not necessary for the technology evaluation experts to become familiar with the concepts of the TLD before their evaluations. The data sheets allowed the evaluations to be performed on a systematic basis. The data sheets (Vol. 3, Pts. A, B, and C) provide detailed information and the basis upon which the diagram (Vol. 2, Pts. A, B, and C) was devised.

\section{Return to Table of Contents.}




\subsection{TECHNICAL APPROACH}

This section describes the overall layout and development of the TLD. The logical progression flows from (DOE) EM Goal $->$ EM Problem $->$ ORNL Problem $\rightarrow>$ Problem Area (Target Constituent) $->$ Reference Requirements $\rightarrow$ Subelement $\rightarrow$ Alternative (Generic Technology) $\rightarrow$ Technology $\rightarrow$ Technology Status $\rightarrow$ Science/Technology Need -> Implementation Need.

Three different levels of information are provided. First, the technologies are evaluated and ranked in Vol. 1, Pts. A, B, and C. Second, more detailed diagrams are provided in Vol. 2, Pts. A, B, and C. Although each large sheet contains the entire logic path, several sheets are necessary to describe each evaluation area. Finally, each single logic path is published as a technology data sheet. These sheets are the most detailed source of information about each technology and are provided in Vol. 3, Pts. A, B, and C.

The information found under each logic element is described below.

EM Goal has three components: cleanup legacy. prevent future insult. and develop environmental stewardship. These problems are shared by all clements of the DOE complex to varying extents.

E.M Problem contains problem areas ageed upon by EM/DOE: such as decommissioning of facilitics (D\&D): cleanup of soils, ground water. and surface water (RA); and WW from inception to final disposition.

ORNL Problem describes the problem areas identified at ORNL. These problem areas have been defined by D\&D. envirommental restoration (ER). and WM staff. The magnitudes of the site problems will be indicated in terms of floor areas. estimated melal tomages. etc.

Problem Area/Constituent addresses subelement-specific list (see below) of problems, all of which are tratceable directly to the ORNL problems.

Reference Requirements refers the reader to the final chapters of Vol. 1. Pts. A. B, and C. Requirements can only be determined after consideration of detailed site-, waste-, and technology-specific characteristics.

Subelement specifies the different components that must be addressed to solve the problem. All D\&D activities have been categorized into the following subelement groups: characterization. decontamination. dismantement. robotics/atutomation. materials disposition. and regulatory compliance. I The subelements for RA are characterization: treatment and fixation: retrieval: robotics/automation: materials disposition: and regulatory compliance. The subelements for $\mathrm{WM}$ alle watste retrieval: chatracterization: processing: stabilization: minimization; packaging. handling. and transportation: disposal: and regulatory compliance rable 2.1 lists the various subelements for D\&D. R.A. and WM.

Table 2.1. Subelement categories in the Technolob Lople Diagram

\begin{tabular}{|c|c|c|c|c|c|c|}
\hline \multirow{2}{*}{$\begin{array}{l}\text { Ares of envionmental } \\
\text { management } \\
\text { Decontaminabion and } \\
\text { decommisuloninc }\end{array}$} & \multicolumn{6}{|c|}{ 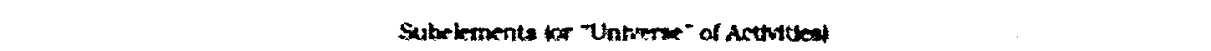 } \\
\hline & Chernotertation & Dacomennination & Dieneatemest & $\begin{array}{l}\text { Pobotloed } \\
\text { mulcunition }\end{array}$ & $\begin{array}{l}\text { Metertab } \\
\text { dispentions }\end{array}$ & $\begin{array}{l}\text { Regulatory } \\
\text { complance }\end{array}$ \\
\hline Rewadtal actlon & Chumotiatulien & $\begin{array}{l}\text { 1. Thedmat } \\
\text { 2. Pundan }\end{array}$ & Retriteral & $\begin{array}{l}\text { Rebotity } \\
\text { entopetion }\end{array}$ & $\begin{array}{l}\text { Metel } \\
\text { Hepenten }\end{array}$ & 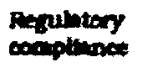 \\
\hline \multirow[t]{2}{*}{ Wreste } & Charnatertintion & 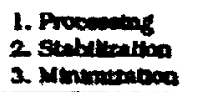 & 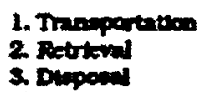 & pototoy & 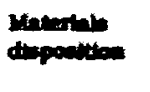 & 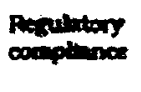 \\
\hline & Cronarating & & & Cocounting & Crowatilins & Cromeutite \\
\hline
\end{tabular}


Alternative defines the general technology approaches that may be applied to the problem.

Technology identifies specific technologies that may be applied to remediate the problem.

Status provides information on the status of the technologies identified in the previous column using the standard categories.

Some accepted technologies are fully developed or commercially available and if so are noted. These terms are used to denote slightly different meanings. Fully developed means that both the basis of the technology and the methods for designing remediation equipment or operations using the method are well known and covered in public literature. Commercially available means that the technology is offered by one or more commercial firms, but the data, design methods, or experience needed to assess the technology are not fully available to the public. The only difference in these two categories is that the public's ability to assess the performance and reliability of the technology is restricted for commercial technology. It suggests an unknown degree of risk in the commercially available technologies that cannot be fully evaluated with generally arailable information (even though the amount of risk may be negligible).

In-Use--technology is presently being used to remediate the identified problem.

Accepted-demonstrated technology exists for usc at ORNL and is accepted by site personnel.

Demonstration--technology is available but is not demonstrated and/or accepted for the problem at ORNL.

Predemonstration--technology is under laboratory-. bench-. or pilot-scale testing.

Evoling Technology-technology status is at a conceptual or preconceptual stage.

- Conceptual--a scientific or knowledge basis for the technology exists.

Preconceptual--only a partial scientific or knowledge basis of the technology exists.

These classifications should provide indirect, relevant intormation on the present view of the short-tem or long-term availability of technologies.

Several different areas are specifically addressed to further clarify the status designations chosen above.

Efficacy--the effectiveness of the technology in remediating the problem. Nomally. quantitative measures are given for the technology's performance in standard practice. such as estimating the final dpm/cm2 of surface contamination for a decontamination technology: the time to cut a 24 -in. pipe for a dismantlement technology: the analysis time and lover cletection limit for at characterization techmology.

Waste-output from the technology. This describes the nature and rolume of both the waste and the potentially useful materials.

Science and Technology Needs are perceived needs. where support or development is needed for an "immature" technology. Science needs are related to the fundamental understanding of the scientific phenomena that form the basis for the technology. These needs are typically for laboratory or bench-scale experiments. Technology development needs identify areas where work is necessary to successfully implement scientific principles that will lead to a technology. Technology improvement needs suggest improvements that will make a current technology more economical to apply, safer, and more effective or efficient. The demonstration of a technology on a site-specific problem is classified as a technology improvement need.

If scientific needs are specified, it should be understood that the needs of scientific technology 
development or improvement are necessary to implement newly developed scientific understanding. Likewise, testing a technology development opportunity implies that technology improvements are also likely to be needed.

DOE funding for a project that addresses the technology deficits is indicated by a Technical Task Plan (TTP) number, Activity Data Sheet number, or other reference number. Other work related to the technology area may also be referenced.

Most new technologies that are not in common use will require a large-scale test or demonstration to show that they are capable of achieving expected results on the site-specific problem. These tests demonstrate that a suitable and workable process or facility can be designed, built, and operated successfully. They show that no unknown condition prevents the process or facility from functioning as it was designed and that the equipment can last an acceptable lifetime. Demonstrations are intended to provide final tests of all aspects of a technology. If, however, particular questions remain about the technology, these are specifically mentioned on the diagram.

Implementation Needs or specialized needs were evaluated for both development of a technology and deplosment of a mature technology. These needs were evaluated in the areas of (1) resources such as linancial or personnel: (2) hardware such as process equipment. development equipment. and computers: (3) soltuare such as models. procedures. computer programs: (t) facilities such als labs. shops. and buildings: and (5) education such as training classes or degreed personnel. An estimate of the cost of the process and any potential cost payback are also given. Only extraordinary needs are highlighted. (i.e., those needs that would require long lead time or unusual procurements, such as line items for facility' construction).

The cost of applying the technology and the payback cost potential has been estimated. There are many reasons for payback. such as reducing the waste volume compared to a reference process. the sale of useable products. and the reduction of labor compared to a reference technology.

When standard laboratory facilities are sufficient. facility needs are not identified. Since the facilities on ORR are relatively extensivepincluding the K-25 Site. ORNL. and the Y-12 Plant--the diagram does not address needs for standard facilities but focuses on unique facility needs.

Howerer. additional conventional facilities may be needed to meet the technology needs for RA at ORNL because the arailable facilities may not provide adequate sapacity for testing the various lechnologies. To assess the andibloility of standard facilitics for these programs. it will be necessary to know $(1)$ the rate at which lectmology derelopment in Oak Ridge will proced and 12 ) the extent al which other programs will competion the facilities.

Return lo Table of Conkens.

\subsection{TECHNOLOGY RANKINGS}

Throughout the technology evaluation a method of conveying information about the ranking and status of each technology and its application is used to communicate separate information about the following:

$\square$ Overall assessment of the applicability of the technology (E, H, M, and L, where $E$ is for essential, $H$ for high, $\mathrm{M}$ for medium, and $\mathrm{L}$ for usefulness.)

Significance of site problem to which the technology is applied ( 1 - 5 is the scale of lowest significance to highest significance). 
$\square$ Time required to bring the technology to an acceptable state for application at large scale (commercial or mature state) at the site. This is expressed in number of years and depends on the current state of its development.

$\square$ The cost for bringing the technology from its present state to a level acceptable for commercial or large-scale use. The costs are presented as $\$ \mathrm{M}$ or $\$ \mathrm{~K}$, which indicates the number of millions or thousands of dollars without escalation.

$\checkmark$ Projected unit processing cost for mature technology (\$ per ft2 or other unit or $\mathrm{N}$ for no estimate). This includes annual ranking costs for software.

An example of a ranking follows:

$$
\mathrm{H}-5-5 \quad(\$ 3.5 \mathrm{M} ; \mathrm{N})
$$

This means that this technology has a high overall usefulness; the technology is estimated to take 5 years before it is ready for application at the site: an approximate expenditure of $\$ 3.5$ million will be required to bring the technology to this state of readiness: and the unit processing cost camnot be projected at the prescint time.

Return wable of Coments.

\subsubsection{Overall Assessment}

Follow ing are the criteria used to determine the overall assessment of a technology and its application.

Waste Generation Reduction--ability of the technology to minimize additional waste generation (1-no confidence. 5-complete confidence).

Compliance with Requirements [Applicable or Relevant and Appropriate Requirements

(ARARs)]--confidence that the technology will comply with applicable. relevant. and appropriate requirements (1-no confidence, 5-complete).

Emirommental, Safety: and Health (ES\&H)-ability of the technology to meet the requirements of ES\&H (1-no confidence. 5-complete).

Versatilit--ability of the technology to meet a wide range of requirements and to adapt to changes in requirements (1-no conficlence. 5-complete).

Complexity-ability of the technology to be deployed without requirements for extraordinary levels of expertise. training. and oversight (1-very high level of requirements. 5-low level of requirements). Techinical Rish-confidence that the technology will work at the sites heing evaluated (1-no confidence. 5-complete confidence).

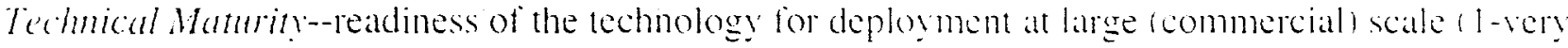
immature-idea for research. 5-ready for commercial application s.

Development Required-relative amount of time required to bring the technology to commercial. application ( 1 -all research. development. and demonstration steps required. 5-now commercial/no tests required).

-- Development Cost-relative cost of bringing the technology to commercial application (1-highest cost for development of a technology within a technical area, 5-no costs, not even field testing).

$\Xi$ Process Cost--relative cost of process in terms of unit production costs in application (1-prohibitively expensive relative to other methods, 5-very inexpensive compared with other methods).

After scoring the criteria, the scores were averaged and the overall assessment rating was determined by the scale in Table 2.2 . 
Table 2.2. Scale for overall assessment rating

\begin{tabular}{|c|c|c|c|}
\hline $\begin{array}{c}\text { Assessment } \\
\text { code }\end{array}$ & $\begin{array}{l}\text { code } \\
\text { meaning }\end{array}$ & Score & Meaning \\
\hline $\mathrm{E}$ & Essentia & & $\begin{array}{l}\text { No other processes or technology available } \\
\text { for essential requirement }\end{array}$ \\
\hline $\mathrm{H}$ & High & 3.67 to 5 & High potential for application \\
\hline $\mathrm{M}$ & Medium & 2.33 to $<3.67$ & Medium potential for application \\
\hline$L$ & Low & $<2.33$ & Low potential for application \\
\hline
\end{tabular}

Return to Tahle of Comtents.

\subsubsection{Status of Technology}

The development state for technology was assessed using the scale provided in Table 2.3.

Table 2.3. Scale tor atatus of technology

\begin{tabular}{|c|c|}
\hline Stale of Tertunology & Sinore \\
\hline Nerpterl & 5 \\
\hline Dethoustratbon ckerded & 4 \\
\hline ETedtumuthathon-evolvth & 3 \\
\hline Conceptust & 2 \\
\hline PTecosereptuat & 1 \\
\hline
\end{tabular}

Retum to Tahle of Comlents.

\subsubsection{Estimates for Time to Maturity}

Defintions for progress of development and time periods. Which were used as guidelines for estimating

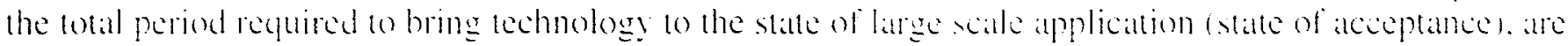
provided in Table 2.t. 


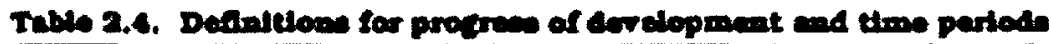

\begin{tabular}{|c|c|c|}
\hline step in dewlopeant & Defaltion of etep & Years \\
\hline \multicolumn{3}{|c|}{ Wor toname } \\
\hline Applad rewearch & 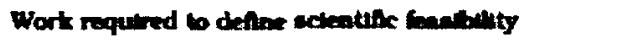 & $1-3$ \\
\hline Drelopinest & 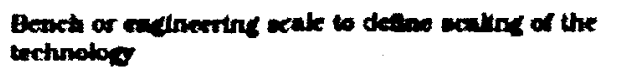 & $2-3$ \\
\hline Frol & 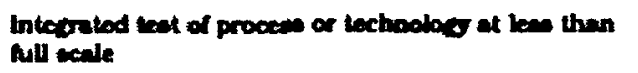 & $3-4$ \\
\hline Prototype dewonimbon & 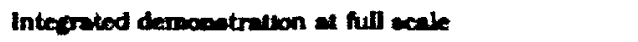 & $3-5$ \\
\hline 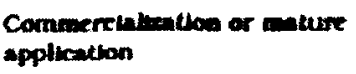 & Appitention of the tochmolog at larte newe & $1-2$ \\
\hline \multicolumn{3}{|c|}{ 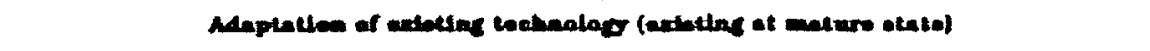 } \\
\hline Syritheates demonucration & 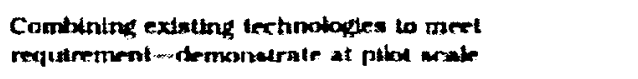 & $2-3$ \\
\hline Finlat test & Treting on the exart ste problems and configuration & $\mathbf{1}-\mathbf{3}$ \\
\hline
\end{tabular}

These stages of development correspond to the state of the technology and are shown in Table 2.5 .

Table 2.5. Correspondence of terms for atate of tbe technology

\begin{tabular}{|c|c|c|c|}
\hline Statna uf terhnokus & Scrore & $\begin{array}{l}\text { Detelopment perind } \\
\text { expreabed by thene }\end{array}$ & 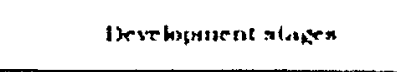 \\
\hline Acreghesl & 5 & Arrullatalc & Mature \\
\hline Denmaniruthen & 4 & Short range & Flokt lest \\
\hline Ihedenewatration & 3 & Medluna ristife & 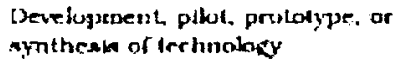 \\
\hline Evolstng-conceplual & 2 & Long ranke & [enelopment \\
\hline Evolstng-preconceptual & 1 & Unkinown & Applled reacarch \\
\hline
\end{tabular}

Return to Tible of Contents.

\subsection{REFERENCES}

1. T. W. Burwinkle. Decontamination and Decommissioning workshop. Oak Ridge National Laboratory. Octoher 29. 1992.

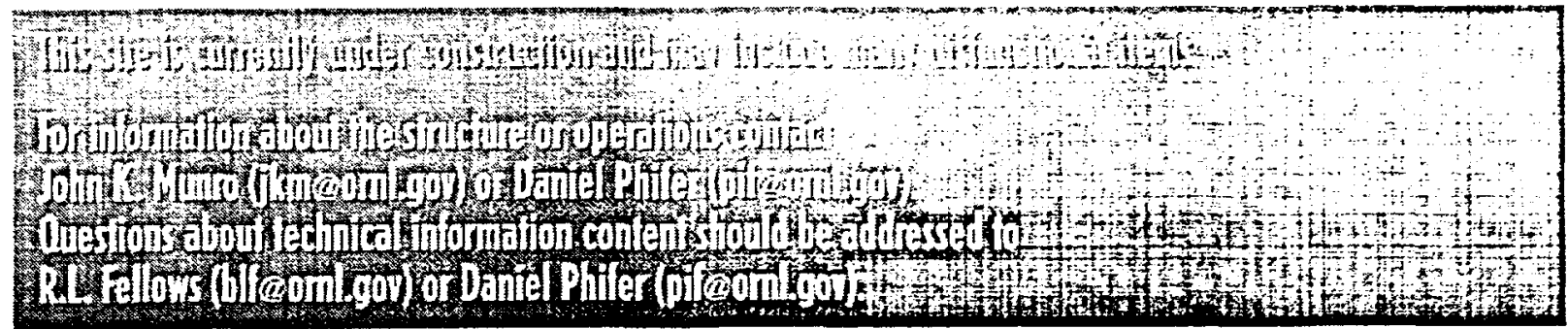




\section{Oak Ridge National Laboralory Technology Logic Diagram Rit 率
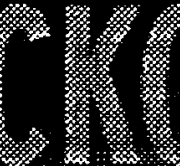

$v 1-1 / 26 / 95$

\section{TLD Forward I ORNL History I ORNL Mission}

\section{TLD Forward}

The Oak Ridge National I aboratory Technology Logic Diagram (TLD) was developed to provide a decision-support tool that relates environmental restoralion (IER) and waste managenent (WM) problems at Oak Ridge National Laboratory (ORNL) to potential technologies that can remediate these problems. The TLD identifies the research, development, demonstration, testing, and evaluation needed to develop these technologies to a state that allows technology transfer and application to decontamination and decommissioning (D\&D), remedial action (RA), and WM activities. It is essential that follow-on enginecring studies be conducted to build on the output of this project. These studies will begin by selecting the most promising technologies identilied in the TLD) and linding an optimum mix of technologies that will provide a socially aceeptable balanee between cost and risk.

The TI.D consists of threc fundamentally separate volumes: Vol. 1 (Technology Evaluation), Vol. 2 (Technology Logic Diagram), and Vol. 3 (Technology Evaluation Data Sheets). Part A of Vols. 1 and 2 focuses on D\&D. Part B of Vols. 1 and 2 locuses on RA of contaminated facilities. Part C of Vols. 1 and 2 focuses on WM. Each part of Vol. 1 contains an overview of the TLD, an explanalion of the program-specilic responsibilities, a review of identified technologies, and the rankings of remedial lechnologies. Volume 2 (P $1 \mathrm{~s} . \Lambda, B$, and $C$ ) contains the logic linkages among EM goals, environmental problems, and the various technologies that have the potential to solve these problems. Volume 3 (Pts. $\Lambda, B$, and $C$ ) contains the TID data sheets, which are expanded versions of logic paths from Vol. 2.

The focus of Vol. I, P1. A. is D\&D, and it has been divided into seven chapters. The first chapter is an introduction, which delines problems specilic to the D\&D Program for ORNL. Chapter 2 provides a general overview of the TLD. Chapters 3 through 6 are the categories which together make un D\&D activities: characterization, dismantlemenv/ disassembly, decontamination, and robotics and automation. The linal chapter contains regulatory compliance information concerning D\&D.

The technology evaluations contained in these volumes are based on the best information available during compilation of the TLD. New or more accurate in lormation is solicited to improve the TLD data base. Please send comments to R. L. Fellows, Editor, Oak Ridge National Laboratory Technology Logic Diagran, Martin Maricua Energy Systems, Inc., P.O. Box 2003, Oak Ridge, TN 37831-7274. FAX (61.5-576-8558).

Relurn to lop.

\section{ORNL History}

The Oak Ridge National Lahoratory (ORNL) was huilt in 1943 as part of the World War II Manhattan Project. Its original mission was to produce and chemically separate the tirst gram quantities of plutonium as part of the national effort to produce the atomic bomb. The peacetime history of the laboratory first began in the late 1940s. Through 1973, ORNL was concerned with the development of nuclear technology for electrical power generation. From 1973 to 1980, ORNL was largely devoted 10 finding solutions for the energy crisis. The primary missions since 1980 have been to conduct applied research and engineering development in support of U.S. Department of Energy (DOE) programs in fusion, fission, conservation, fossil, and other energy lechnokgies and to perform basic scientilic research in selected areas of the physical and life sciences. The 
Laboratory also operates "user facilities" for the benclit of university and industry researchers and supplies radioactive isotopes that are not otherwise commercially available.

Return to top.

\section{ORNL Mission}

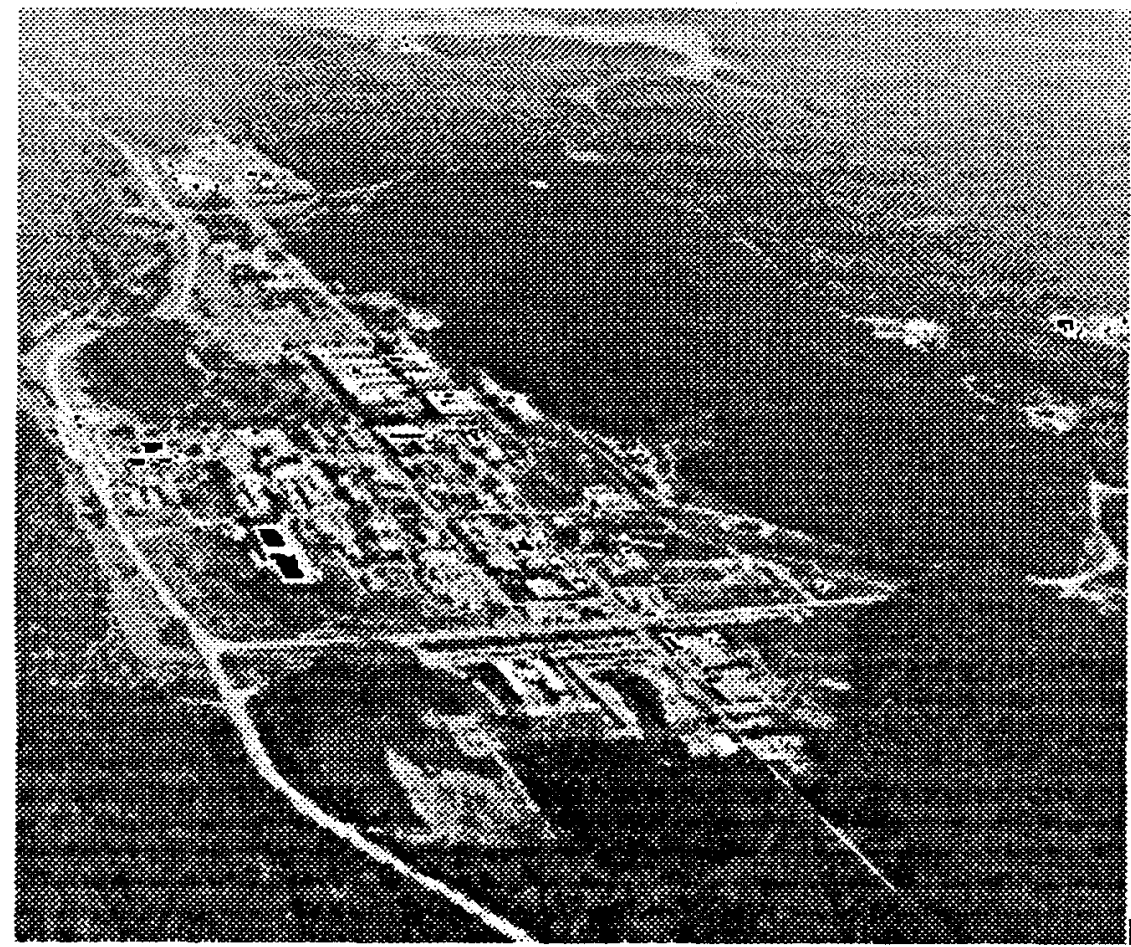

Fig 1.1

ORNL. which is managed by Martin Mariclta Jenergy Systems, Inc., for DOE, is one of the nation's premier research institutions (sce Fig. 1.1 for acrial view of (ORNI.). The primary mission of the Laboratory is to perform leading-edge research and development (R\&D) in support of the nonweapons roles of DOE. Significant elements of ORNL's mission are to perform basic and applied research that is of importance to the nation; to provide the scientific and technical community with unique national user facilities: 10 improve the nation's competitiveness through technology development and transfer by parnering universities and industry; and wo improve science and math education through contributions to the national initiative. ORNL. will accomplish the mission through its core competencies:

- encrgy production. conservation. and utilization technologics:

- malcrials sciences and enginecring:

- physical. chemical. and engincering sciences;

- biological and life sciences:

- environmental sciences and technologies:

- computational scicinces: and

- manulacluring sciences and lechnologies.

The principal sponsor of ORNI 's work is DOE, but, in a larger sense, the Laboratory serves many nationalfleven internationalfleustomers. ORNI. slaff are involved in rescarch on global energy and environmental problems and in the development of technologies that will improve U.S. competitiveness in international markets. The Laboratory's more fundamental scientitic research, much of which is done in collaboration with researchers from around the world, contributes 6) the storehouse of human knowledge: this work. therefore. has a very broad customer base. In the conception, construction. and operation of national research facilitics. the Laboratory's customers are drawn from major segments of the scientific and technical community. Much of the applied research and technology development work at ORNL is expected to provide services for other government agencies and private companies.

\section{Return tolop.}




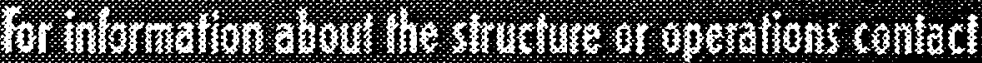

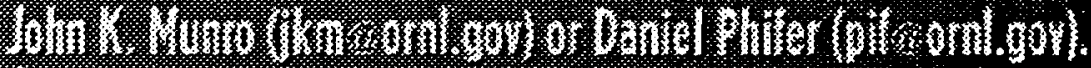

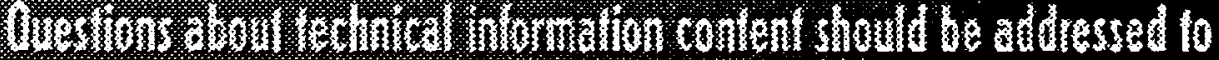

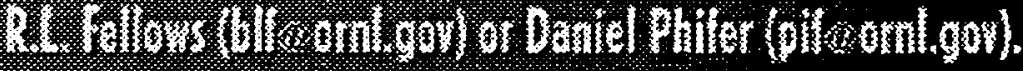




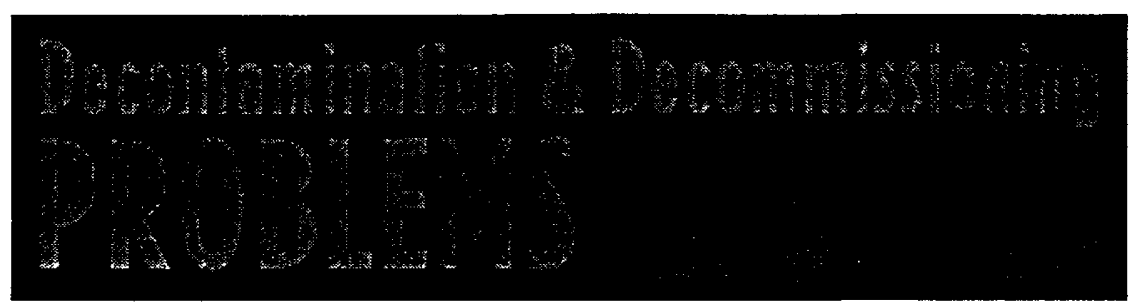

$v 2-2 / 22 / 95$

\section{Building 3001 ORNL Graphite Reactor (view Fig. 1.2)}

was the first reactor constructed at ORNL, being placed in service in 1943 at a $1-\mathrm{MW}$ power level. It was an air-cooled, graphite-moderated and -reflected. heterogeneous. natural-uranium-fueled reactor. The support facilities for Graphite Reactor include the Graphite Reactor Filter House (3002). the Graphite Reactor Fan House (3003). and the Graphite Reactor Exhaust Stack (3018).

List of principle contaminants.

\begin{tabular}{|c|c|c|}
\hline Hohest contantration & Loration & contarninance \\
\hline $2-R / h$ & 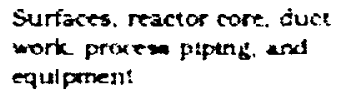 & 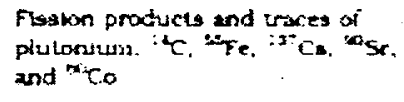 \\
\hline
\end{tabular}

\section{Building 3005 Low-Intensity Test Reactor (see Fig. 1.2)}

Was a water-moderated and-cooled reactor. using enriched uranium as fuel and beryllium as a reflector for the purpose of supplying a variety of irradiation facilities for ORNL and other research groups. The reactor was originally designed for a $500-\mathrm{kW}$ power level but was converted to a $3-\mathrm{MW}$ testing reactor prior to permanent shutdown in 1968. The Low-Intensity Test Reactor is supported by an air cooler (3077).

List of principle contaminants.

\begin{tabular}{|c|c|c|}
\hline 18test rontaminaten & Loration & 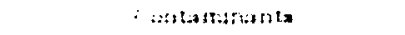 \\
\hline $2 \mathrm{k} x \mathrm{sing} \mathrm{k} / \mathrm{b}$ & 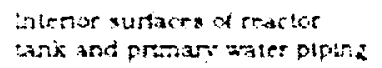 & 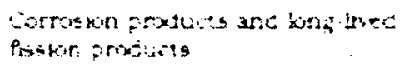 \\
\hline
\end{tabular}

\section{Building 3042 Oak Ridge Research Reactor (see Fig. 1.2)}

was a 20-MW materials testing reactor built in 1958. It was used for neutron beam experiments, isotope production, and materials irradiation. It was shut down in 1987, and all fuel was removed. The Oak Ridge Research Reactor is supported by a pool cooling tower and annex (3086), the cooling tower (3103), the heat exchanger pit (3102), the demineralizer (3004), and the pump house (3085).

\section{List of principle contaminants.}


poweot conterination

Loconation

Contrumenate

$>0.000 \mathrm{R} / \mathrm{h}$

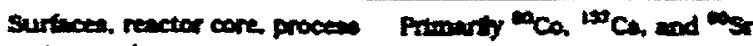

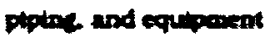

\section{Building 3087 Oak Ridge Research Reactor Heat Exchanger (see Fig. 1.2)}

This water-to-air heat exchanger was the original heat dissipation system for the Oak Ridge Research Reactor. When the reactor power level was increased from $20 \mathrm{MW}$ to $30 \mathrm{MW}$ in 1960 , the radiators were replaced by a water-to- water heat exchanger and cooling tower heat dissipation system.

List of principle contaminants.

\begin{tabular}{|c|c|c|}
\hline Fithes! conlamenetion & Loration & Contamtnants \\
\hline $250.400 \mathrm{R} / \mathrm{h}$ & $\begin{array}{l}\text { Surtsces. teactor cort pror:=s } \\
\text { puptnt. and equlptarnt }\end{array}$ & Primarty ${ }^{\infty} \mathrm{Co},{ }^{150} \mathrm{c}$ \\
\hline
\end{tabular}

\section{Building 3505 Metal Recovery Facility}

Was a pilot- and small-scale production nuclear fuel reprocessing plant used for the processing of rarious waste-solution. scrap, and miscellameous fuel clements for the recovery of uranium. plutonium. neptunium, and americium.

List of principle contaminants.

\begin{tabular}{|c|c|c|}
\hline Fidieat contarntnation & Loration & contamsanu \\
\hline $\begin{array}{l}\text { Q0ing and ih } \\
2.500 .000 \text { dpen } 1100 \mathrm{~cm}^{2}\end{array}$ & Cell tralls and Givers & Moot liveng :2: $\mathrm{Cs}$ \\
\hline
\end{tabular}

\section{Building 3506 Waste Evaporator Facility}

recoived the liquid low-level waste (LLLW) strams from ORNL laboratories and other procesing acis during the 1950 s for concentration prior to final dispostion by shale fracture lechniques.

List of principle eontaminamts.

\begin{tabular}{|c|c|c|}
\hline Phest contummaton & isatwon & sotatritants \\
\hline 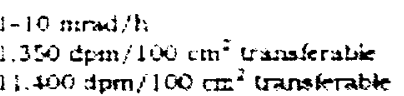 & 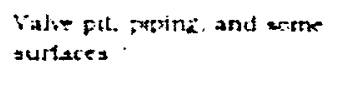 & $\therefore C \mathrm{csant} " \mathrm{Sr}$ \\
\hline
\end{tabular}

\section{Building 3515 Fission Product Pilot Plant}

was used in the fission product recovery development program for the separation of curie quantities of various radionuclides from LLLW streams. It was abandoned in 1958 when it was replaced by the FPDL.

List of principle contaminants. 


\begin{tabular}{|c|c|c|}
\hline 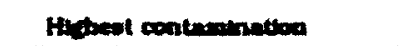 & Lacestes & Contumenome \\
\hline 1-100 R/ tpries to entombeneod & 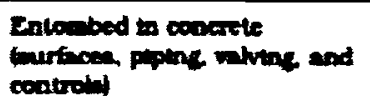 & 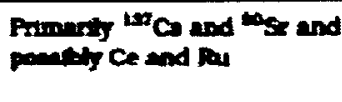 \\
\hline
\end{tabular}

\section{Building 3517 Fission Product Development Laboratory Inactive Cells}

went on line in 1958 to separate kilocurie quantities of fission products from Redox- and Purex-type waste streams. In 1975, the chemical processing cells were shut down and maintained in protective storage. Some initial decontamination was performed, but subsequent funding restrictions limited the scope of this effort.

List of principle contaminants.

\begin{tabular}{|c|c|c|}
\hline Fithes: conlemitnation & Loxation & Contamunanto \\
\hline $10 \cdot 10.000 \mathrm{R} / \mathrm{h}$ & $\begin{array}{l}\text { Cell wartares. proces } \\
\text { equiptnent and piping }\end{array}$ & 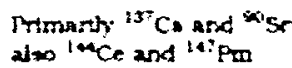 \\
\hline
\end{tabular}

\section{Building 4507 High-Level Chemical Development Laboratory}

was designed and operated as a laboratory and small-scale pilot plant for development studies of ratator-fuel processing. scparation and recovery of transuranic (TRL') materials. and sepaltation of fission products from aqueous wastes.

List of principle contaminants.

\begin{tabular}{|c|c|c|}
\hline Fisthest conlamtnation & Loratian & Contarntsanco \\
\hline $250.000 .000 \mathrm{dpm} / 100 \mathrm{~cm}^{2}$ & Cell murfuces and equipenent & 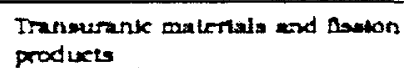 \\
\hline
\end{tabular}

\section{Building 7500 Homogeneous Reactor Experiment}

housed wo experimental aqueous homogeneous ractors that were developed for nuclar pouer appliation andses. The Homogeneous Reator Experiment is supported hy the waste evaptraten

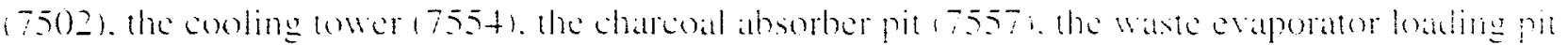

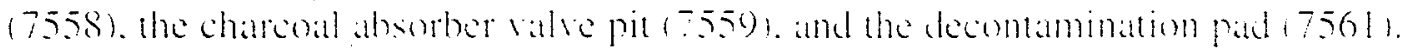

List of principle comtaminamts.

\begin{tabular}{|c|c|c|}
\hline Hucheal contamination & Lorition & Contaminants \\
\hline $\begin{array}{l}600 \mathrm{R} / \mathrm{h} \\
32,000 \mathrm{dpm} / 100 \mathrm{~cm}^{2} \\
\operatorname{lnmax}\end{array}$ & $\begin{array}{l}\text { Cell walli, equipment wurtaces. } \\
\text { and proceso piptint }\end{array}$ & 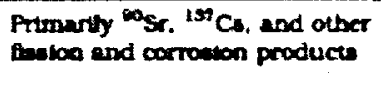 \\
\hline
\end{tabular}

\section{Building 7503 Molten Salt Reactor Experiment}

was a single-region, unclad graphite-moderated, homogeneous-fueled reactor built to investigate the practicality of the molten salt reactor concept for central power station applications. The circulating 
fuel solution was a mixture of lithium-, beryllium-, and zirconium-fluoride salts, containing uranium fluoride as the fuel. The Molten Salt Reactor Experiment is supported by the filter pit (7511), the exhaust stack (7512), the cooling tower (7513), the supply air filter house (7514), and the diesel generator house (7555). Figure 1.5 shows the elevation layout; the reactor cell can be seen in Fig. 1.6 (black and white photo 1 color photo).

List of principle contaminants.

\begin{tabular}{|c|c|c|}
\hline Hupeel contamination & Locactan & Contuntente \\
\hline $2200 \mathrm{R} / \mathrm{h}$ & 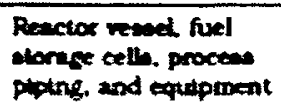 & $\begin{array}{l}\text { Primant co and ocher } \\
\text { trutan producte }\end{array}$ \\
\hline
\end{tabular}

\section{Building 7852 Old Hydrofracture Facility}

was an experimental and operational plant for the injection of waste grout into a fractured shale formation. The experimental design was tested in 1964p1965 using dilute and concentrated watste solutions. Beginning in 1966. operational injections of concentraled liquid waste from the OR. $\backslash L$ LLLW system were routinely made until fitcility shutdown in 1980. A pump house and four hulk storage bins comprise the Old Hydrofractuc Facility ancillary facilities. Figure 1.7 is a photongraph of the ficility.

List of principle contiminants.

\begin{tabular}{|c|c|c|}
\hline Hithest ronearntraton & Loration & Concandrante \\
\hline skih tmav & $\begin{array}{l}\text { Surtaces. equipment and } \\
\text { protns }\end{array}$ & $\begin{array}{l}\text { Paskion protuxts. "Cs. "se. } \\
\text { art }{ }^{\prime \prime C} \mathrm{C} 0\end{array}$ \\
\hline
\end{tabular}

\section{Building 9201-3 Mezzanine Storage Tank ( Y - 12)}

is a 3000 -gal storage tank that was used from 195810 1969. Lntil recently it was believed hat this tank was used as a reservoir for machine shop cutting oil during development of molten salt reatur technology. Howerer recent intermation stegend that this tank held cleaning solution for the

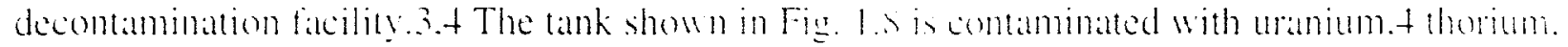
molion silt. and an oil isidac.

List of promiple comaminams.

\begin{tabular}{|c|c|c|}
\hline Hixhes rontartiazixn & Loxztwon & Contamblanta \\
\hline 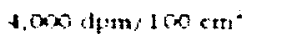 & Surtuce & $\therefore \pi, 01$ \\
\hline
\end{tabular}

\section{Building 9201-3 Coolant Salt Technology Facility (Tritium Test Loop)}

was built in 1958 and was used to support the development of molten salt reactor technology and specifically to study the effects of injecting tritium into a flow of boron trifluoride.

List of principle contaminants. 


\begin{tabular}{|c|c|c|}
\hline Hapeet conturitnation & Dochen & Contentenente \\
\hline 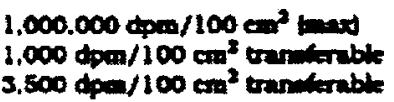 & 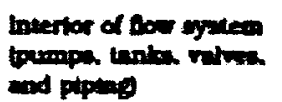 & mous \\
\hline
\end{tabular}

\section{Building 9201-3 Molten Salt Corrosion Loop}

was built in 1958 for the preparation and handling of fuel for molten salt reactor technology development and the Molten Salt Corrosion Loop.

List of principle contaminants.

\begin{tabular}{|c|c|c|}
\hline Hothesf contammulion & Location & Contaminanta \\
\hline $\begin{array}{l}50.000 \mathrm{dpm} / 100 \mathrm{~cm}^{2} \text { imax } \\
1.200 \mathrm{dpm} / 100 \mathrm{~cm}^{2} \text { transierable } \\
3.500 \mathrm{dpm} / 100 \mathrm{~cm}^{2} \text { tranm teralide }\end{array}$ & $\begin{array}{l}\text { Interiof of fuel thanding } \\
\text { cell and support } \\
\text { equalprnent }\end{array}$ & $\begin{array}{l}\text { 2xy, } 200 \text { Th. and low leveb of } \\
\text { transiersble Be }\end{array}$ \\
\hline
\end{tabular}

\section{Building 9419-1 Decontamination Facility}

Mas used to decontaminate equipment and materials associated wh the development of molten salt reachor cechnology from 1958101969.

List of principle contaminants.

\begin{tabular}{lll}
\hline Hicheat contamenataon & Loration & Contaranants \\
\hline Low keveis of atpha & Surface & Tntum
\end{tabular}

\section{Shielded Transfer Tanks}

Wer used to ship 137C S-loaded ion exchange resins for procssing from Richland. Washington. w ORNL.

List of principle contaminants.

\begin{tabular}{|c|c|c|}
\hline Bithest ontarmution & Sxalxon & 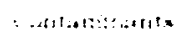 \\
\hline
\end{tabular}

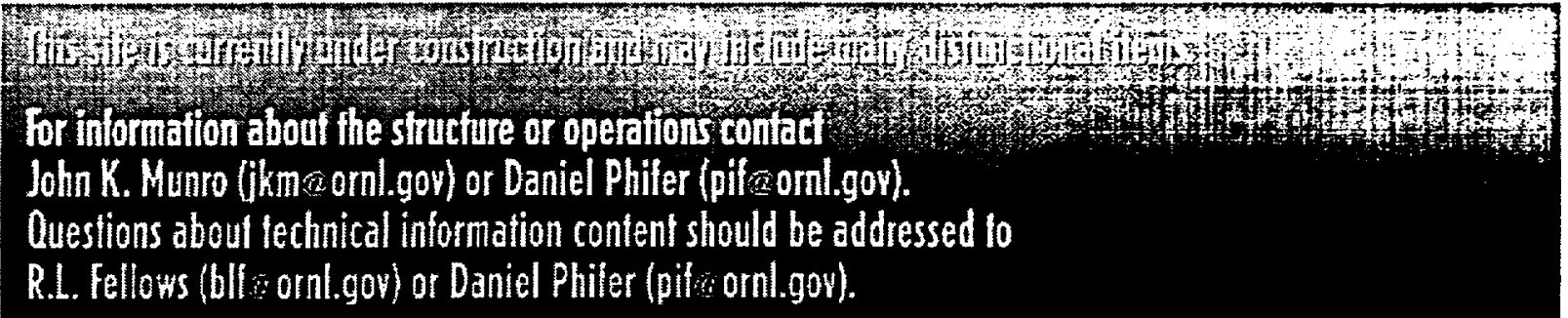


Titie: MAGNETIC RESOHANCE IMAGING _ _ CHAR-58-OL

EM Problem: Decontamination and decommissioning

ORNL Problem: See Appenaix A, list is

Problem Area/Constituents: Physical

Reference Requirements: Refer to the Regulatory Compliance chapter of Vol. 1 (Pt. A, B, or C as appropriate! for potentially applicable proposed and promulgated environmental laws, signed and pending agreements for the oak Ridge Reservation, radiation protection standards, DOE orders, and nonregulatory guidance. As site- and waste-specific characteristics are provided for each technology, specific regulatory requirements wili be specified.

Subelement: Characterization

Alternative: Laboratory methods

Technology: Magnetic resonance imaging (MRI, MMRI). Imaging technology using the nuclear magnetic resonance phenomenon; most applications currently detect hydrogen but others are possible.

\section{Status: Accepted}

Temporai areas of evaiuation: precreatment; treatment; posttreatment Ceployment evaluation: Manual applications Driver evaluation: Fisk and technical assessments Appicable contaminant evaluation: Inorganic (U, Tc, $\mathrm{Cr}, \mathrm{CrO}$, $\mathrm{Hg}$. $\mathrm{Fb}, . .$.$) ; organic loiz, polychiorinated biphenyls, volatile organic$ compounds, trichloroethylene, .... radioactive (à, á, fl)

Waste produced-None, entire sample is used in an in situ determination cverail cost-To be deteminad

Efficacy/strengthsflhis mature, yet growing, technology has the potential to allow nondestructive inspection of the internal structure of materials and evaluation of system integrity. This type of technology may provide very useful information, not only for identifying how to dismantle an unknown, but for verifying the status of waste form integrity. Not applicable to metal (steel) containers.

Soience/Technology Neds: Model studies for waste forms and various equipment parts are needed.

Implementation Needs: Instrumentation is neaded. Development costs are estimated at $\sim \$ 200 k$. Very high capitai equipment costs.

Auchor: D. P. HofEmann; $615-574-3890^{\circ}$

References: M. P. Ancire; Diaiog File No. 265; 60 ; id No. 0004; $33381 ;$ bit. 
TIEIE: DATA/SIGNAL TRAISMISSION - ROBA-13-OL

EM Problem: Decontamination and decommissioning, remedial action, and waste management activities

z-jo Site Problem: Buildings, eguipment, buried waste, storage tanks, and contaminated soils

Frobiem Area/Constituents: Radicactive and hazardous materials encountered in characterization, decontamination, dismantlement, and retrieval operations

Reference Requirements: Refer to the Regulatory Compliance chapter of Vol. 1 (Pt. A, B, or C as appropriate) for potentially applicable proposed and promulgated environmental laws, signed and pending agreements for the Dak Ridge Reservation, radiation protection standards, DOE orders, and nonregulatory guidance. As site- and waste-specific characteristics are provided for each technology specific regulatory requirements will be specified.

Eubilement: Roboticsiatomation

Alternatives: Mechanical; mobilit:

Technology: Data/signal transmission. Methods of transmitting data and control signals zum the robotic device to the control station are required for all remote operations. Various options available to the. designer include umbilical cords, radio frequency, microwave, and iaser-based systems. The option chosen will depend on the particular application and the transmission rate required.

\section{Ststus: Accepted}

diditional Comments: Fadio frequency is limited in transmission rate. Lasers and, to a lesser extent, microwaves depend on line-of-sight between the transmitter and the receiver, and umbilical cords lead to potential snagging probiems.

Eificacy-High. Dataisignal transmission system are required for ail robotic applications.

waste-None.

Overall Costfdevelopment costs will range from sok for umbilical cords to $\$ 200 \mathrm{~K}-\$ 500 \mathrm{~K}$ for advanced microwave systems.

Science/Technology Needs: None. The necessary technology currently exists.

Inplementation Neads: Integration of existing technology into robotic systems and testing representative enviroments to ensure functionality.

Author: J. N. Herndor bis-5-4-:20

References: Personal oxperience anc discussions with other MMEs personnel 

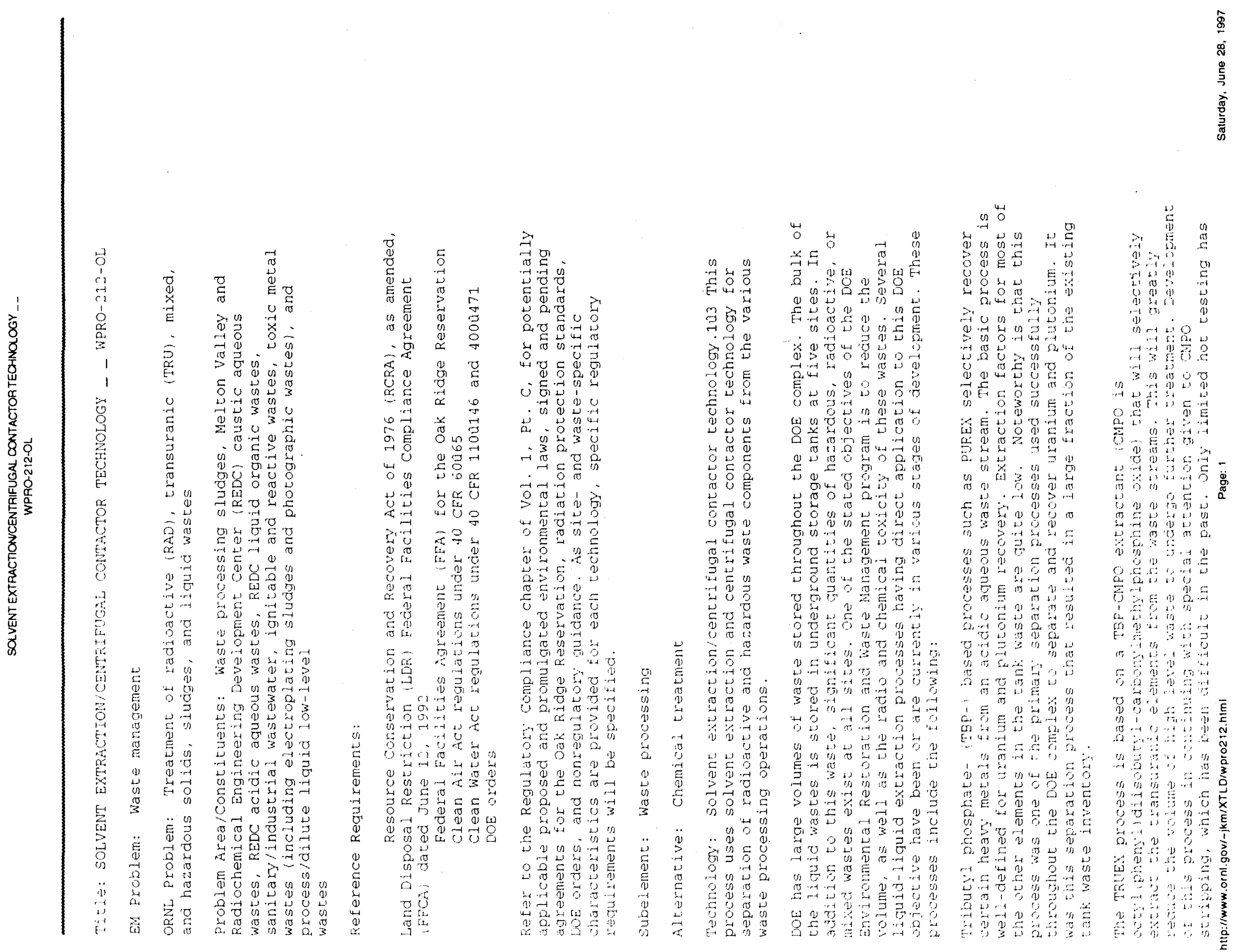
DEtr conducted to date.

ivumerous other extractants are also under investigation. These include the amides and diamides. These are considered potential alternatives to the CMP-based TRUEX process and offer the advantage of not containing phosphorus. The French are focusing considerable attention on the diamides. Limited work on those extractants is also under wä in the U.S. These processes are not as well developed as the TRUEX process.

Drwin ethers offer the potential of tairoring a solvent to a specific solute to be extracted. Currentiy work is under way at onNL to develop extractants for technetium and americium fron alkaline sodium nitrate solutions.

To reduce the volume of high-level waste stored and to minimize its generation, it is important to isolate and separate the long-Iived actinides from fission products. These long-lived isotopes can then be stored, mixed into nuclear fuel for power-reactor generation. or they can be destroyed by transmutation in high-intensity, accelerator-produced high-neutron-flux systems.

One of the most promising separative schemes to isolate the heavy actinides from the lanthanides and other fission products is call "TALSPEAK. "The name "TALSPEAK" is derived from Trivalent Actinide-Lanthanide Separations by rissphorus-reagent Extraction trom dqueous complexes. In this process, the stoaration of trivalent actinides and rare earths is accomplished by first - outracting the twe groups ot elements into HDEHP (di(2-ethylhexylphosphoric acid; from a carborilic acid solution and then partitioning the crivalent sctinides into an aqueous phase by stripping the HDEHP extractant with an acjueous carboxylic acid solution containing the complexing agent DTPA (diethyienetriaminepenta- acetic acid).

Development is necessary to determine the effects of fission product impurities (:uch as $2 \mathrm{r}$ and Mol and changes in the acidity on the separation performance. specifically, how the insoluble species of these elements, which typically ollect at the intertace in the extraction process, might zffect separation.

Status: Demonstration predemonstration. The separation of hesvy metals, uranium, actinides, and other radionuclides using centrifugal contactor-based solvent extraction tecinology has been an accepted process at Loe nuclear sites ful ver 25 years. A number of specific flowsheets have been developed to separate various constituents. However, other possible applications it this technology may require considerable research and development and Genonstration (RDED: .

\section{Science/Technology Needs:}

Configuration of a chemical process flow sheet for (1) dilute concentrations of contaminants $1 e . g .$, heavy metals, uranium, other radionuclides, etc. relative to the potentially higher concentrations of other contaminants in the waste stream : 1 determination of extraction stages required to reduce waste content of the liquid phase to below regulatori limits for release

Demonstrativi af closed-100p operation, in wich extractant is

recovered for reuse with surrogre wasto stäem

Detemination of materials oi construction contecibie with the

wmpcistion of the waste stream

Inplementation Needs: RDL costs for a specific application of the technology are estimated to be \$1Mù\$2.5M 11902 dollars!. Payback for the technology is application-specific but could be sigrificant considering alternate treatment technologies and waste disposal costs.

Authors: K. E. P?limen.615-574-7069 and $k$. T. Jubin/615-574-65e6

Reishences:

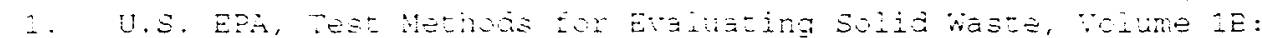

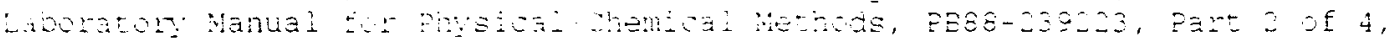
$\therefore$ onder $198 \mathrm{~s}$ 
SOLVENT EXTRACTIONCENTRIFUGAL CONTACTOR TECHNOLOGY

WPRO-212-OL

Centrifugal Contactors, $300 \mathrm{j} 19$, Procedings of International Solvent Extraction conference, 1980 .

3. M. E. What ley, The Removal of Residual Tributyl Phosphate from Aqueous solvent Extraction Effiuent streams by organic Diluent washing, ORNL/CFRP-88/24, Martin Marietta Energy systems, Inc., Oak Ridge Natl. Lab., September 1988. 


\title{
Distribution
}

\author{
R. L. Fellows \\ D. N. Fry \\ R. G. Gilliland \\ P. L. Gorman \\ D. R. Hamrin \\ A. J. Luffman \\ D. W. McDonald \\ J. K. Munro \\ D. Phifer \\ T. M. Rosseel \\ C. A. Valentine \\ J. D. White \\ DOE-WFO \\ OSTI (2)
}

